\title{
Gynura procumbens: An Overview of the Biological Activities
}

\author{
Hui-Li Tan ${ }^{1}$, Kok-Gan Chan ${ }^{2}$, Priyia Pusparajah ${ }^{1}$, Learn-Han Lee ${ }^{1 *}$ and Bey-Hing Goh ${ }^{1 *}$ \\ ${ }^{1}$ Biomedical Research Laboratory, Jeffrey Cheah School of Medicine and Health Sciences, Monash University Malaysia, \\ Bandar Sunway, Malaysia, ${ }^{2}$ Division of Genetic and Molecular Biology, Faculty of Science, Institute of Biological Sciences, \\ University of Malaya, Kuala Lumpur, Malaysia
}

\section{OPEN ACCESS}

Edited by:

Lyndy Joy McGaw,

University of Pretoria, South Africa

Reviewed by:

Bhekumthetho Ncube, University of KwaZulu-Natal, South Africa

Adeyemi Oladapo Aremu, University of KwaZulu-Natal, South Africa

*Correspondence: Learn-Han Lee lee.learn.han@monash.edu; Bey-Hing Goh

goh.bey.hing@monash.edu

Specialty section:

This article was submitted to

Ethnopharmacology,

a section of the journal

Frontiers in Pharmacology

Received: 17 December 2015

Accepted: 26 February 2016

Published: 15 March 2016

Citation:

Tan H-L, Chan K-G, Pusparajah P.

Lee L-H and Goh B-H (2016) Gynura

procumbens: An Overview of the

Biological Activities.

Front. Pharmacol. 7:52.

doi: 10.3389/fphar.2016.00052
Gynura procumbens (Lour.) Merr. (Family Asteraceae) is a medicinal plant commonly found in tropical Asia countries such as China, Thailand, Indonesia, Malaysia, and Vietnam. Traditionally, it is widely used in many different countries for the treatment of a wide variety of health ailments such as kidney discomfort, rheumatism, diabetes mellitus, constipation, and hypertension. Based on the traditional uses of G. procumbens, it seems to possess high therapeutic potential for treatment of various diseases making it a target for pharmacological studies aiming to validate and provide scientific evidence for the traditional claims of its efficacy. Although there has been considerable progress in the research on $G$. procumbens, to date there is no review paper gathering the reported biological activities of $G$. procumbens. Hence, this review aims to provide an overview of the biological activities of $G$. procumbens based on reported in vitro and in vivo studies. In brief, $G$. procumbens has been reported to exhibit antihypertensive, cardioprotective, antihyperglycemic, fertility enhancement, anticancer, antimicrobial, antioxidant, organ protective, and antiinflammatory activity. The commercial applications of $G$. procumbens have also been summarized in this paper based on existing patents. The data compiled illustrate that $G$. procumbens is a potential natural source of compounds with various pharmacological actions which can be utilized for the development of novel therapeutic agents.

Keywords: Gynura procumbens, medicinal plant, biological activity, ethnopharmacology, Bai Bing Cao

\section{INTRODUCTION}

Gynura procumbens (Lour.) Merr. (Family Asteraceae), is a small plant $\sim 1-3 \mathrm{~m}$ in height. The stems are fleshy and the leaves are ovate-elliptic or lanceolate (Rahman and Asad, 2013). It has scientific synonym names such as Gynura sarmentosa DC and Cacalia sarmentosa Blume (Quattrocchi, 2012). The plant leaf is commonly consumed and scientifically it has been shown to be safe for consumption (Rosidah et al., 2008). In Malaysia, the fresh leaves of G. procumbens are commonly eaten raw and in Thailand, the leaves are also used for cooking (Kaewseejan et al., 2015). In Malay, G. procumbens is called Sambung Nyawa which means "prolongation of life" whereas in Chinese, it is called Bai Bing Cao which means "100 ailments" (Bodeker et al., 2009). This is because it has been utilized in traditional medicine both systemically and for topical application for treatment of different types of illnesses and diseases (Krishnan et al., 2015). For example, it is widely used to relieve kidney discomfort in Indonesia and people have been using it for the treatment of fever in Vietnam. In Thailand, it is commonly used to alleviate inflammation, rheumatism, and to cure viral ailments (Wiart, 2006). The beneficial properties of G. procumbens have been attributed to the 
presence of bioactive compounds such as flavonoids and glycosides in this plant (Akowuah et al., 2001, 2002).

Throughout the years, intensive research done on $G$. procumbens has provided extensive scientific evidence of its therapeutic potential. The present review aims to provide an overview of the biological activities of $G$. procumbens with reference to the available literature. The vast potential medical applications of $G$. procumbens based on the consolidation of the scientific findings of research on this plant are also highlighted.

\section{BIOLOGICAL ACTIVITIES}

\section{Antihypertensive and Cardioprotective Activity}

Hypertension is a key risk factor for several cardiovascular diseases including coronary vascular disease and stroke (Lu et al., 2012). Over the past few decades, significant effort has been expended to explore medicinal plants with antihypertensive therapeutic effect, including G. procumbens (Lam et al., 1998). To date, the administration of $G$. procumbens has been reported to result in significant lowering of systolic blood pressure and mean arterial pressure in hypertensive rats (Hoe and Lam, 2005; Kim et al., 2006; Hoe et al., 2007). Additionally, the treatment with G. procumbens extract has also resulted in significant decrease in heart rate, strong negative chronotropic, and negative ionotropic effects at rats' right atrium and left atrium respectively (Hoe et al., 2011; Kaur et al., 2012; Abrika et al., 2013).

Angiotensin (Ang)-converting enzyme is important for blood pressure regulation. It converts Ang I into Ang II, the peptide hormone with potent vasoconstrictive effects (Lote, 2006). Interestingly, the blood pressure-lowering effect of G. procumbens was associated with its inhibitory effect on angiotensin-converting enzyme activity (Hoe et al., 2007). In addition to that, G. procumbens has direct inhibitory effect on the activity of Ang II. This was demonstrated in the study that reported the inhibition of Ang II- induced contraction of aortic rings treated with fraction of G. procumbens (Poh et al., 2013). In terms of mechanism of action, G. procumbens possibly antagonizes the vasoconstrictive effect of Ang II through endothelium-dependent pathways that involve the activation of nitric oxide and prostaglandin release (Poh et al., 2013). This is supported by the reduction of inhibitory effect of G. procumbens aqueous fraction on Ang II-induced contraction in the presence of cyclooxygenase inhibitor and endothelial nitric oxide synthase inhibitor (Poh et al., 2013). This was also supported by another research finding which found increased serum nitric oxide level in hypertensive rats treated with G. procumbens extract (Kim et al., 2006).

Another possible mechanism of the vasodilatory effect of $G$. procumbens is inhibition of extracellular $\mathrm{Ca}^{2+}$ influx. Vasocontraction caused by phenylephrine, calcium and potassium chloride was shown to be antagonized by $G$. procumbens extracts. This was probably due to the blocking of receptor-operated and/or voltage dependent calcium channels as well as opening of potassium channel (Hoe et al., 2011; $\mathrm{Ng}$ et al., 2013). Therefore, G. procumbens potentially serves as an antihypertensive agent with cardioprotective activity due to its ability to target various mechanisms including the renin-angiotensin system and calcium influx which are crucial players in the pathophysiology of hypertensive conditions.

\section{Antihyperglycemic Activity}

G. procumbens is commonly used for diabetes treatment in traditional medicine and its hypoglycemic effect has been reported in in vivo studies (Hamid et al., 2004; Algariri et al., 2014). One intriguing finding on G. procumbens, is its specificity in inducing hypoglycemic effect only in diabetic animals as it has been shown to cause a significant decrease in fasting blood glucose levels and suppression of glucose elevation during glucose tolerance test in diabetic rats but not normal rats (Zhang and Tan, 2000; Algariri et al., 2013).

The effect of $G$. procumbens treatment on insulin level has been investigated. Hamid et al. (2004) has reported the stimulation of insulin secreting cell lines by G. procumbens extract. However, the exposure of clonal pancreatic cells with extract of G. procumbens did not stimulate insulin secretion (Hassan et al., 2008). These contradicting results might be due to the differing response of different cell lines when treated with G. procumbens. Therefore, its effect on insulin secretion has been further tested using in vivo studies. However, no significant change has been observed in plasma insulin level in diabetic rats treated with the extracts, implying that the hypoglycemic activity of $G$. procumbens does not rely on insulinotropic activity but may instead be due to its extra-pancreatic effect (Hassan et al., 2008; Lee et al., 2012).

Other pathways explored in the research include experiments on the antidiabetic effect of $G$. procumbens focusing on glucose uptake activity. The findings showed G. procumbens treatment stimulated glucose uptake on 3T3 adipocytes. Furthermore, an enhancement of activity was found in the presence of insulin (Bohari et al., 2006). Further validation was then conducted via in vivo work. The report showed an enhanced uptake of glucose by muscle tissue of diabetic rats, indicating a direct effect of G. procumbens extract on glucose uptake and utilization at the peripheral levels (Hassan et al., 2010).

With reference to metabolic pathways, G. procumbens was found to exert an effect on glucose metabolism in liver. It was demonstrated to cause phosphorylation and inactivation of glycogen synthase kinase 3 (GSK3) in the liver of diabetic rats, suggesting that the hypoglycemic action of $G$. procumbens is due to either direct or indirect effects on the upstream component(s) activities in the insulin signaling pathway (Gansau et al., 2012). In addition, it stimulated an increase in activity of glucokinase and pyruvate dehydrogenase and phosphorylation of ATP-citrate which are known to play roles in glucose metabolism (Kang et al., 2015). Furthermore, an enhancement of liver hexokinase, phosphofructokinase and fructose-1,6-bisphosphatase specific activity were also found following treatment. This indicates G. procumbens stimulated an increase in utilization of hepatic glucose and decreased endogenous glucose production (Lee et al., 2012).

There has also been work examining the hypoglycemic effect of $G$. procumbens in combination with other herbal therapies. 
It was observed to achieve a stronger hypoglycemic effect when G. procumbens was used together with Azadirachta indica or Andrographis paniculata (Pramono and Nugroho, 2015). The synergistic effect is postulated to be related to the diverse range of active compounds present in the extract combination (Sunarwidhi et al., 2014). Taken altogether, the current evidence suggests the presence of bioactive principles which possess insulin mimetic properties in G. procumbens (Hassan et al., 2010).

\section{Sexual and Reproductive Function Enhancement Activity}

Aside from direct treatment of diabetes, research on $G$. procumbens has also explored its potential in treating infertility, which is one of the complications of diabetes (RamalhoSantos et al., 2008). G. procumbens was found to exhibit an effect on sexual and reproductive function as the treatment with G. procumbens significantly increased sperm count, sperm motility, and reduced the percentage of sperm mortality of diabetic rats (Sani et al., 2008). G. procumbens was also demonstrated to have the aphrodisiac properties as evidenced by an increase in mounting frequency of diabetic rats following the treatment (Noor and Radzuan, 2012). In term of enzymatic activity, G. procumbens was found to promote testicular lactate dehydrogenase activity (Hakim et al., 2008). This finding can be correlated to improved fertility because lactate dehydrogenase is known to play a crucial role in spermatogenesis (Kaur and Bansal, 2004). Overall, studies clearly suggest that G. procumbens may improve the reproductive function of infertile diabetic males, particularly through an increase in sperm counts, quality, and motility.

\section{Anticancer Activity}

G. procumbens has long been used as traditional treatment for cancers such as leukemia, uterine, and breast cancers (Agustina et al., 2006). This has prompted scientific exploration of the antitumor activity of G. procumbens (Maw et al., 2011). Short term (10 weeks) treatment of the ethanolic extract was found to suppress the progression of nitroquinoline 1-oxide-induced tongue carcinogenesis during initiation phase. Longer period (26 weeks) of administration was demonstrated to lead to high suppression of oral carcinogenesis (Agustina et al., 2006). The ethanolic extract was also shown to be effective against carcinogenetic effect of 7,12-dimethylbenz(a)antracene on liver (Nisa et al., 2012). G. procumbens has been also tested on osteosarcoma cell line. The treatment has resulted in inhibition of cell proliferation and was observed to suppress the invasive and migratory abilities of the cancer cells (Wang et al., 2013). Recently, ethanolic extract of $G$. procumbens was shown to cause about $80 \%$ decrease in azoxymethane-induced aberrant crypt foci in rats which indicates potential in preventing colon cancer (Shwter et al., 2014). G. procumbens has also demonstrated its potential in preventing breast cancer. It was shown to cause effective suppression in proliferation of breast cancer and epithelial cells of mammary glands. Besides, the further studies conducted has proven that the treatment of G. procumbens was able to reduce the tumor incidence in the animals tested (Meiyanto et al., 2007; Hew et al., 2013; Gofur et al., 2015).
Mechanistically, G. procumbens inhibits the initiation phase of carcinogenesis. The treatment with ethanolic extract caused a significant reduction in expression and activity of cytochrome P450 enzymes such as CYP3A4, CYP1A2, and CYP1A1 (Afandi et al., 2014; Ghofur et al., 2015). This inhibition may lead to a lower risk of cancer as it will result in a reduction in the conversion of the respective procarcinogens to cancer triggers (Afandi et al., 2014). In addition, G. procumbens treatment has also been shown to stimulate expression of glutathione-transferase which is involved in the detoxification of carcinogenic compounds. These activities help to prevent cancer formation at its initiation phase (Hamid et al., 2009; Ghofur et al., 2015).

Cancer patients frequently consume herbal medicine as complementary and alternative medicine while undergoing chemotherapy (Cheng et al., 2010). In view of this, co-treatment studies of $G$. procumbens and chemotherapy drugs have been carried out. The combination of $G$. procumbens extract with doxorubicin or 5-fluorouracil resulted in strong synergistic effect against breast and colon cancer cells (Meiyanto and Jenie, 2007; Nurulita et al., 2011, 2012). However, co-treatment of G. procumbens with cisplatin appeared to be antagonistic as this combination failed to further suppress cancer cell proliferation (Nurulita et al., 2011). This demonstrates that the concomitant use of G. procumbens with different chemotherapy drugs might result in variable treatment efficacy.

In general, the blockade of angiogenesis pathways will result in inhibition of growth, invasion, and metastasis of tumor cells (Hamid et al., 2011). G. procumbens was shown to exhibit antiangiogenic activity as the treatment caused inhibition in expression of vascular endothelial growth factor and prevented formation of new blood vessels on fertilized chicken eggs (Jenie et al., 2006; Hamid et al., 2013).

Based on the reported studies, G. procumbens appears to be an effective chemotherapeutic agent against a wide range of cancer cell types and it exerts its anticancer activities via the modulation of various points of carcinogenesis including cancer initiation, cell proliferation, metastasis, and angiogenesis.

\section{Antimicrobial Activity}

The increasing incidence of resistant strains of malaria, viruses and also bacteria to currently available drugs makes the search for alternative therapeutics from herbal plants a key area of interest (Tan et al., 2015). The antiplasmodial activity of G. procumbens was first reported by Vejanan et al. (2012). The research shows that G. procumbens extract exhibits chemo-suppression effects toward malarial parasite strains of Plasmodium falciparum 3D7 and Plasmodium berghei NK65; possibly via direct inhibition of GSK3 or indirect action on pi3K/Akt pathway. Besides, the ethanolic extract of aerial plant parts has been demonstrated to exhibit virucidal and antireplicative activity against herpes simplex virus HSV-1 and HSV-2. This was validated in a clinical trial on patients with recurrent herpes labialis where treatment with G. procumbens herbal gels reduced the number of patients infected with HSV (Jarikasem et al., 2013). Meanwhile, the antibacterial activities of $G$. procumbens have also been tested with the extract exhibiting antibacterial activity against gram-positive and gram-negative bacteria such as Bacillus 

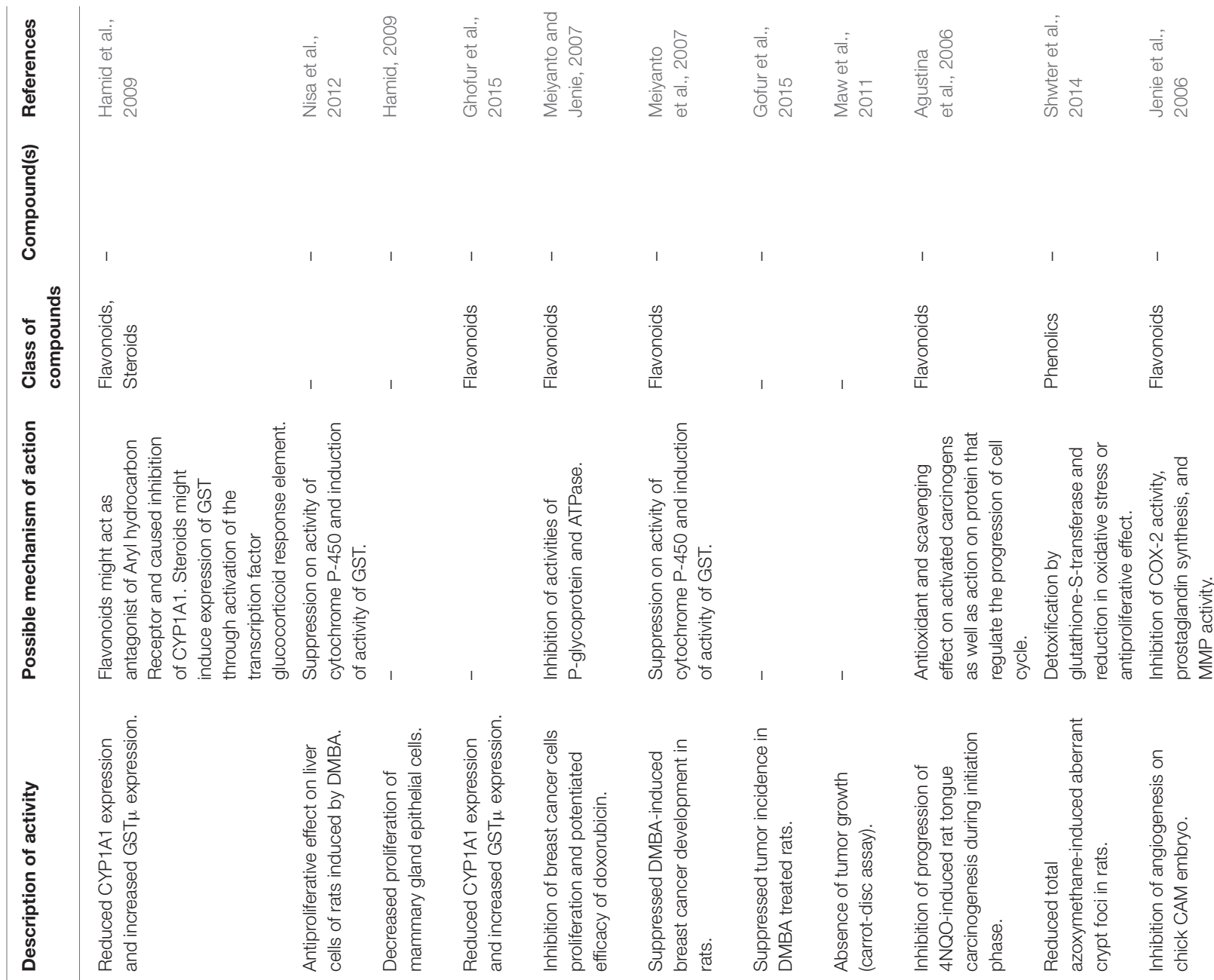

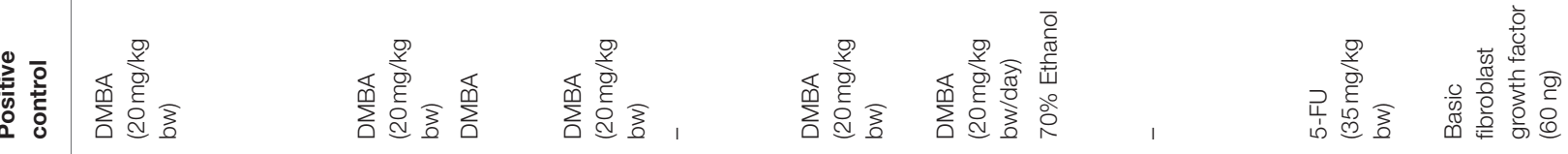

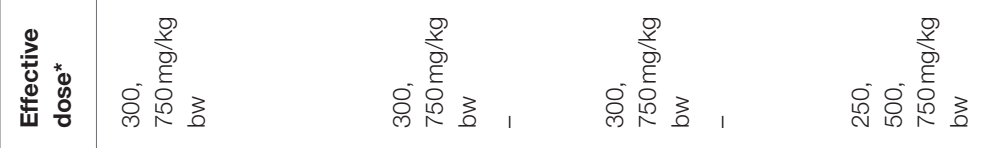

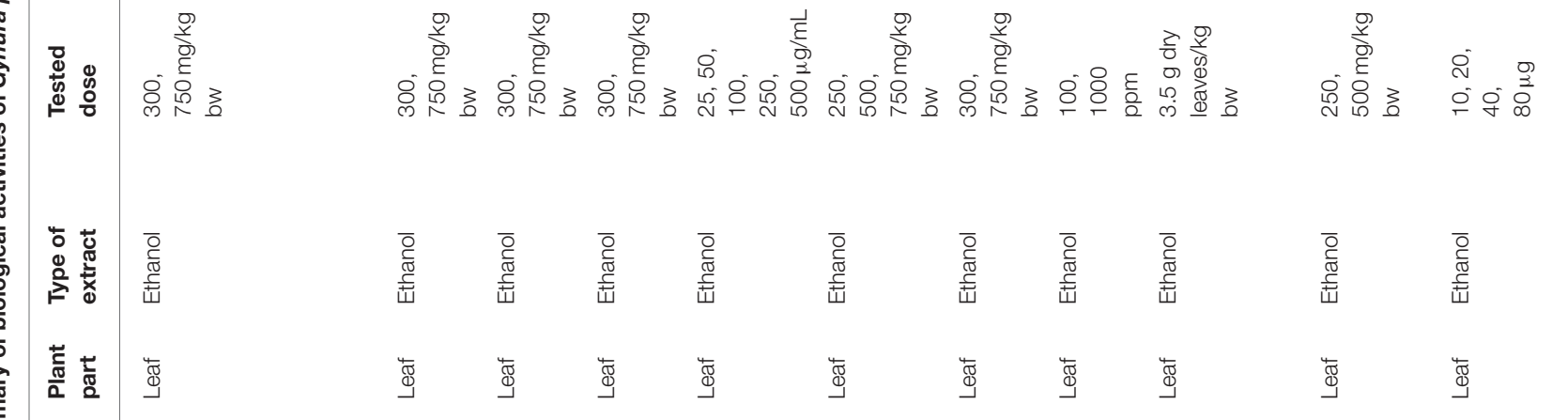




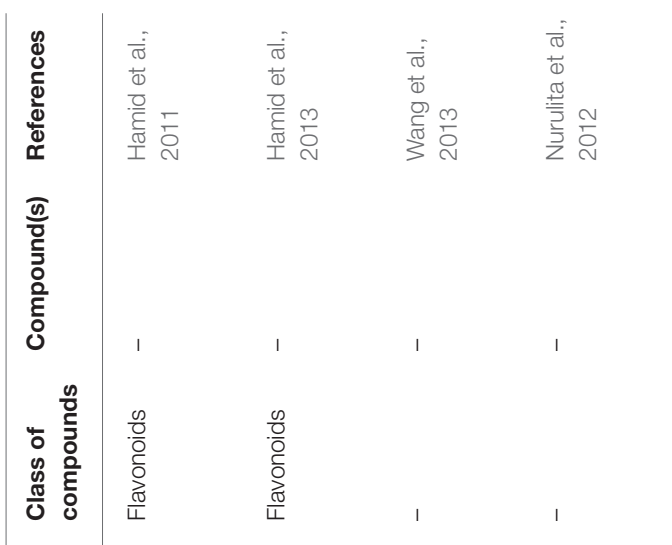

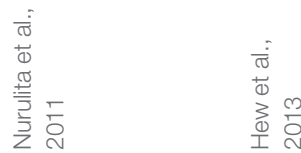

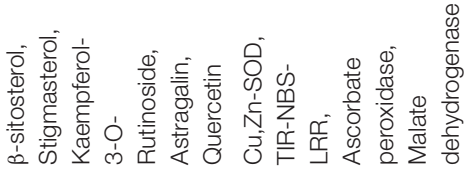

$\frac{8}{0}$
$\frac{0}{0}$
$\frac{0}{10}$
$\frac{0}{10}$

$\frac{0}{\frac{0}{9}} \frac{0}{0}$

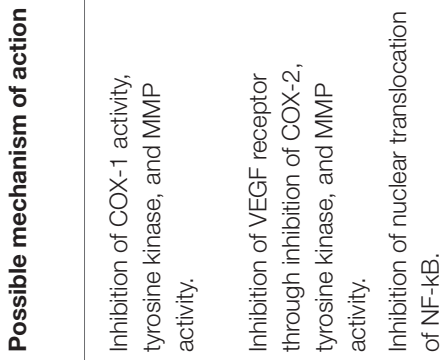
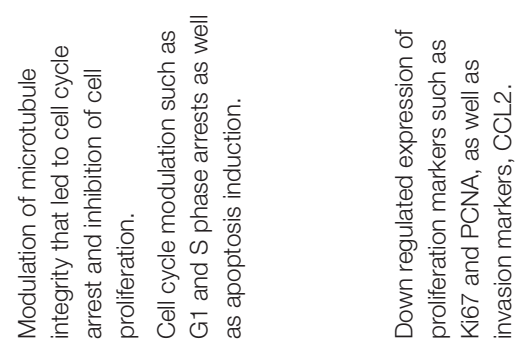

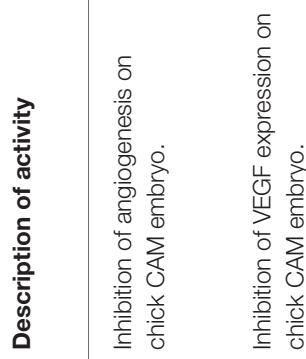
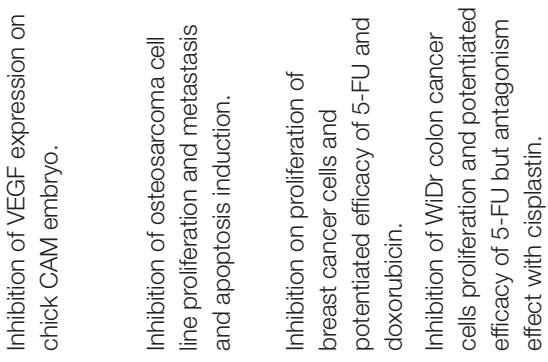

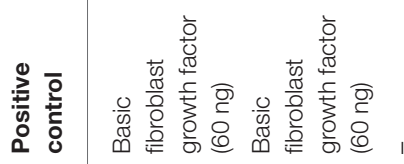

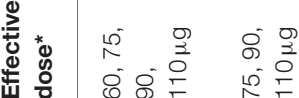

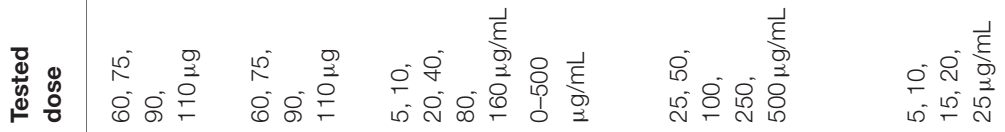

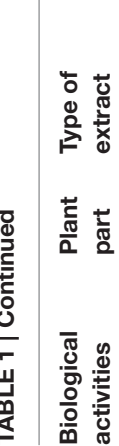

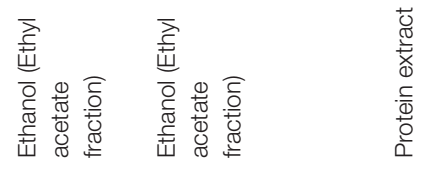

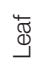

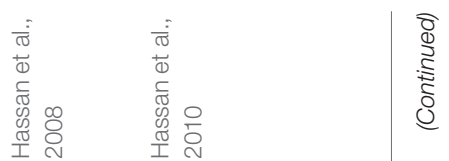

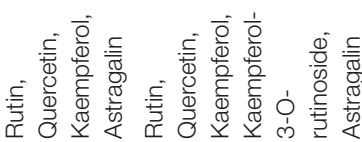

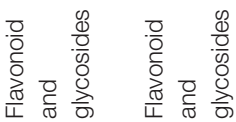

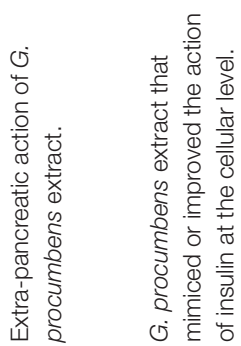

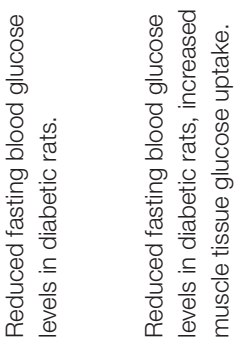

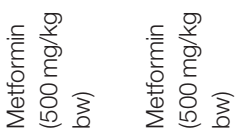

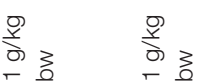

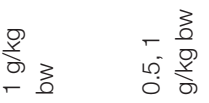

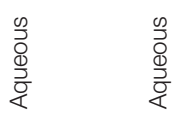

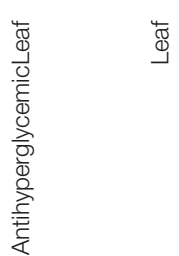




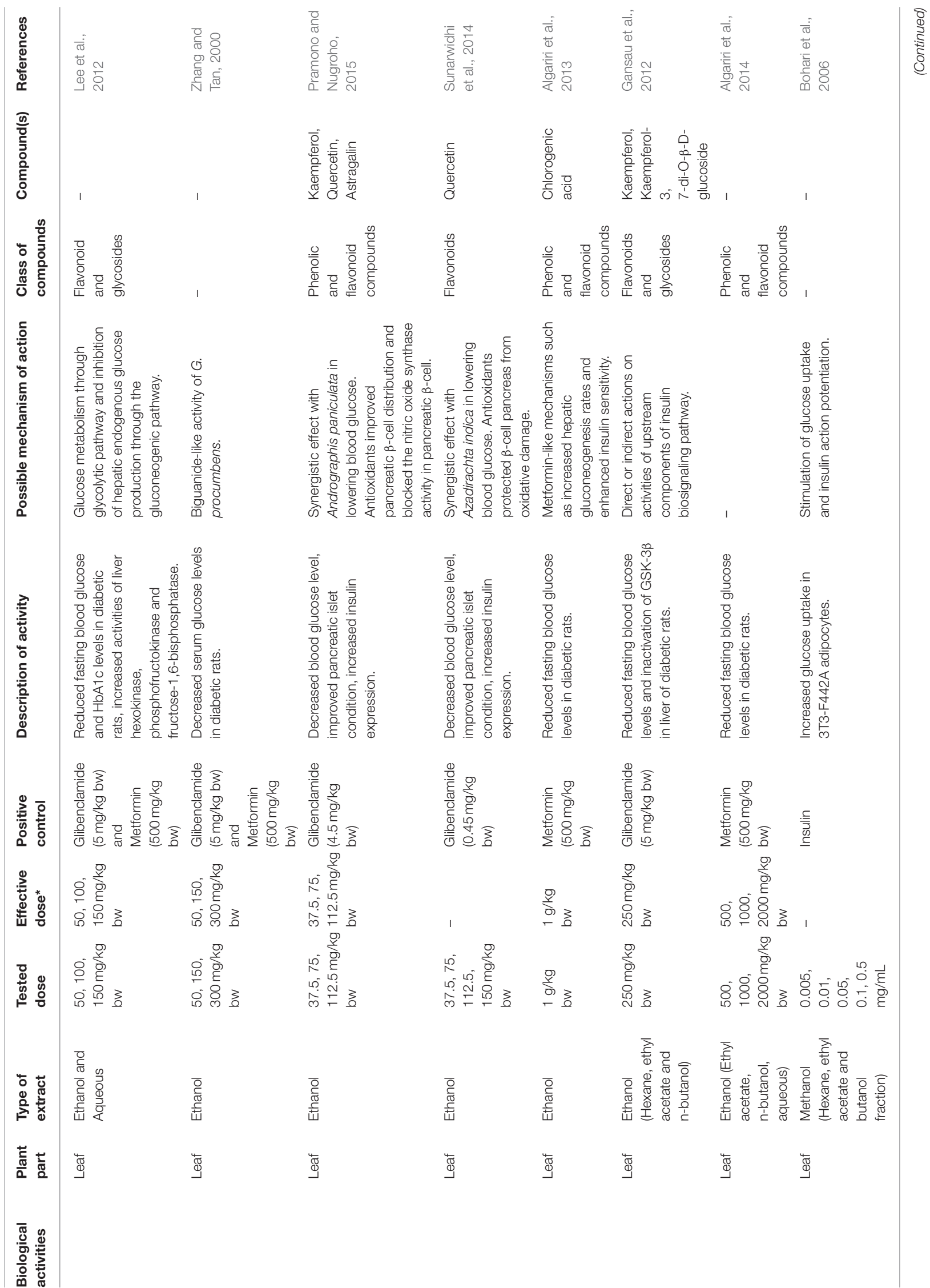




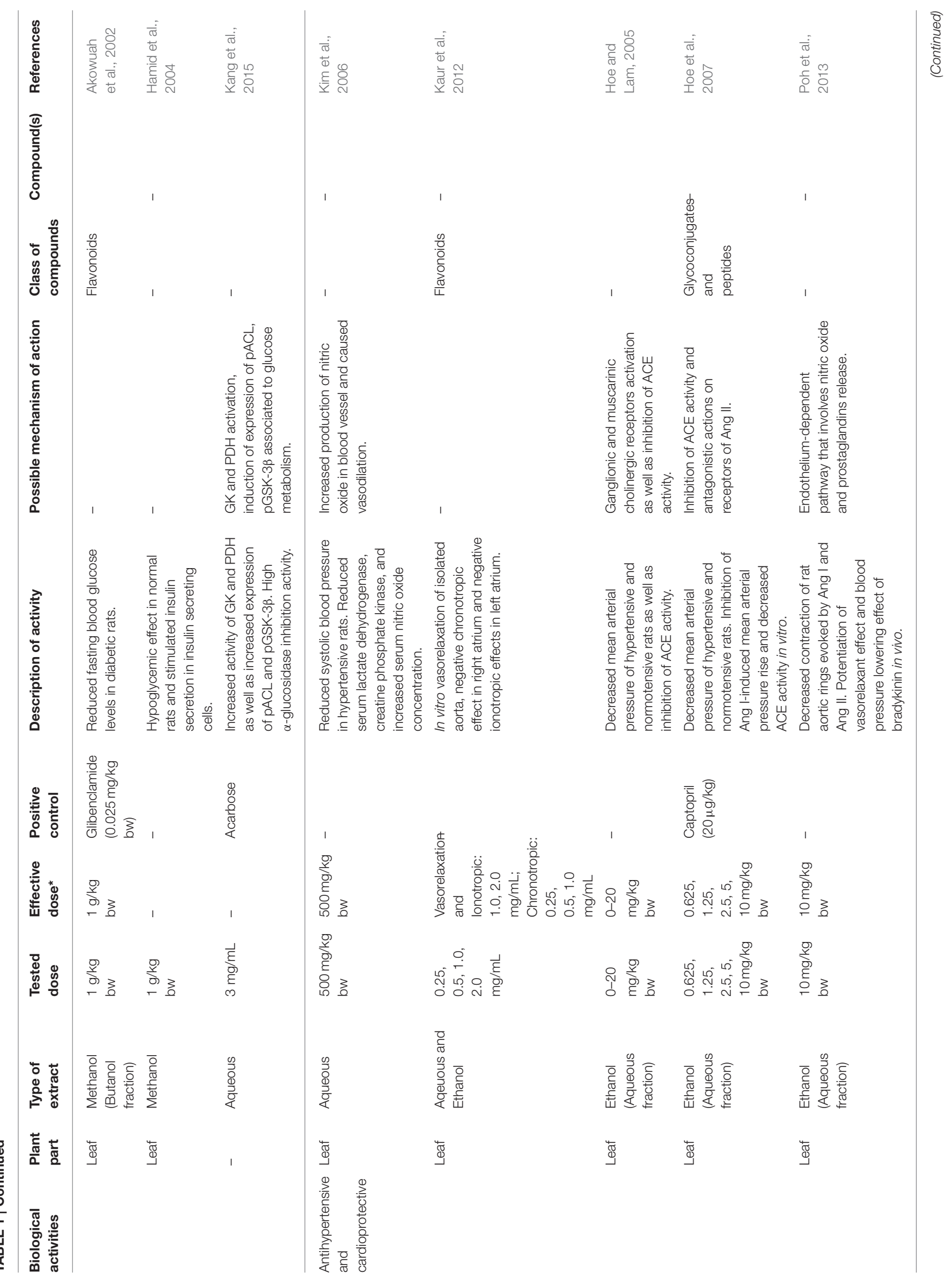




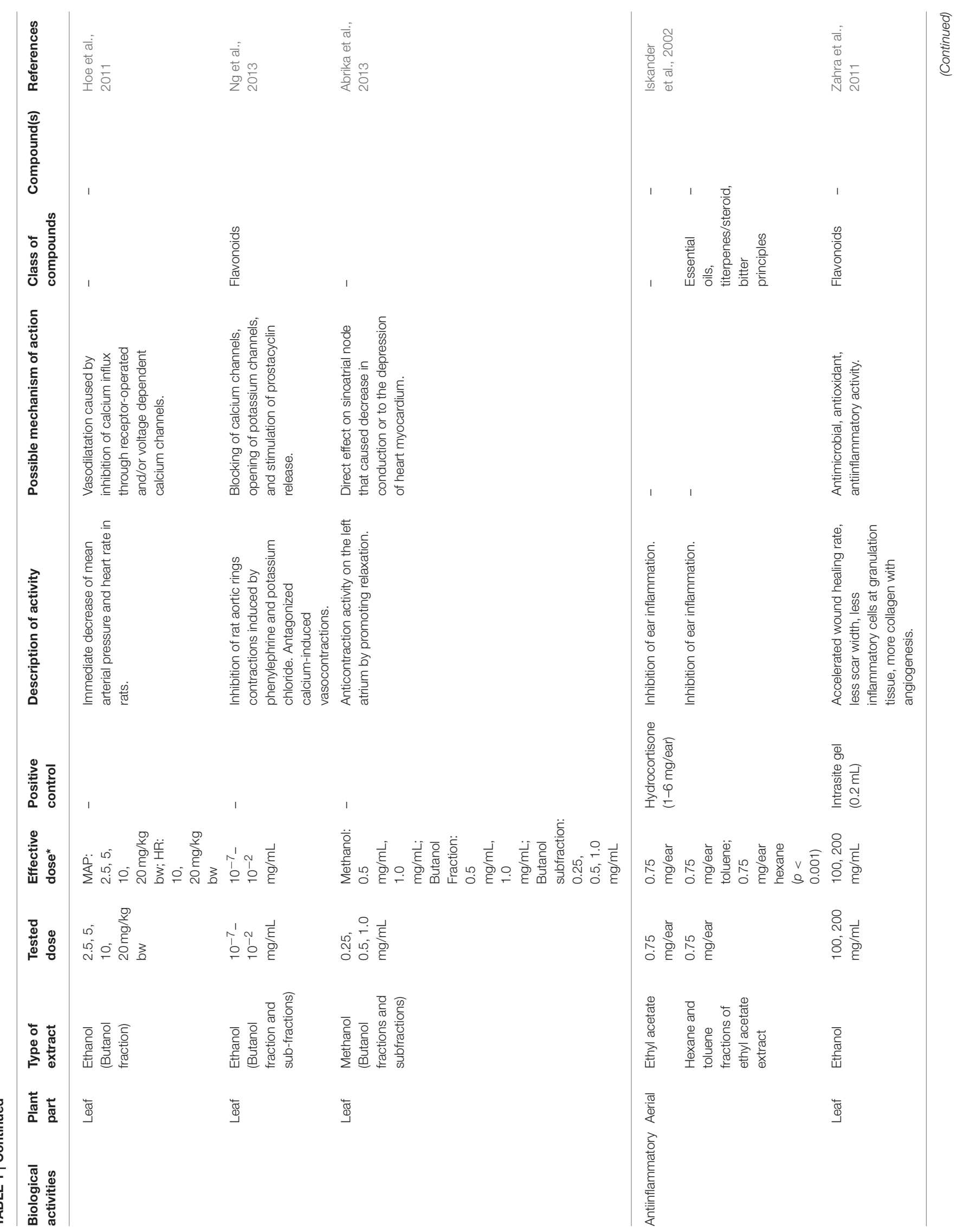




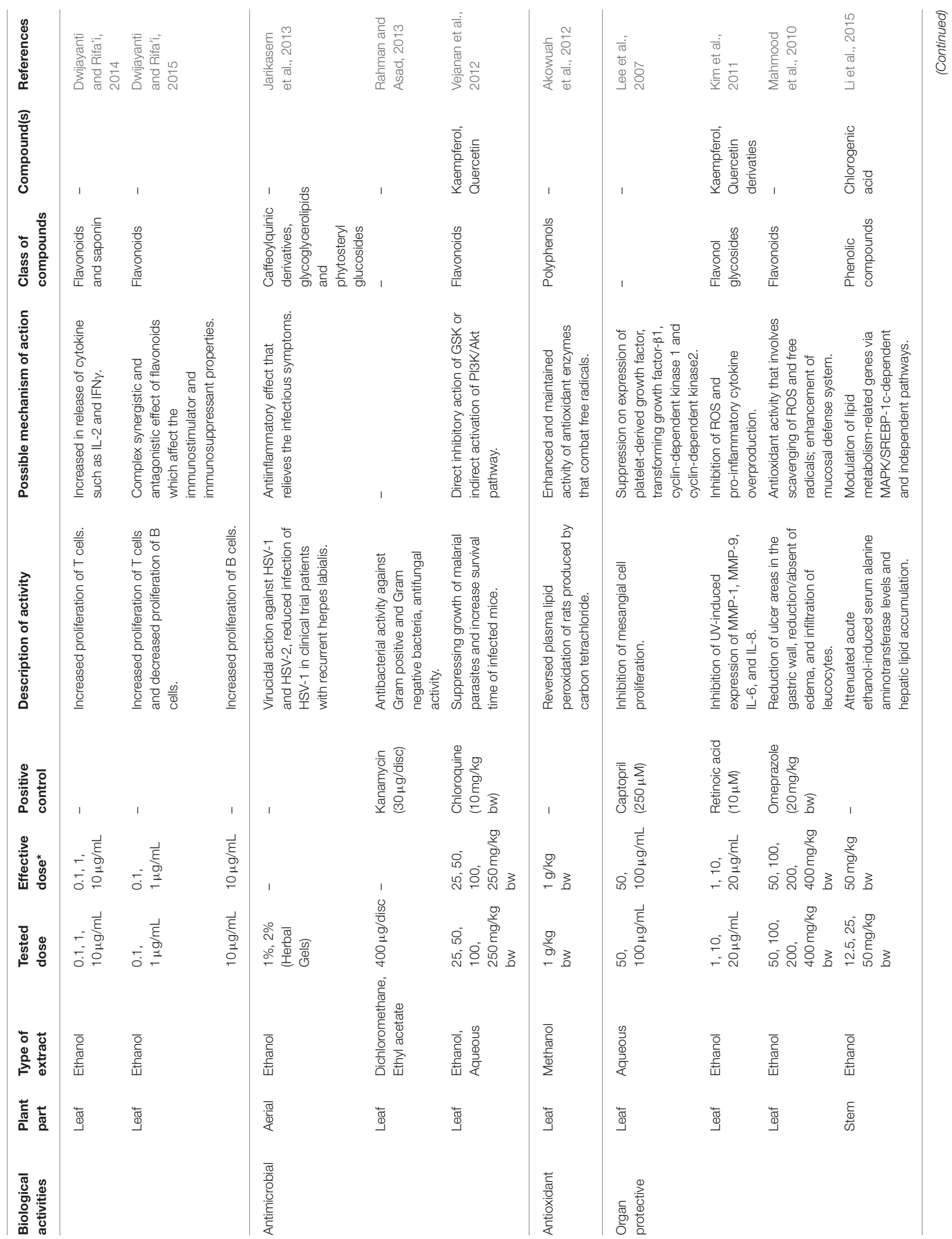




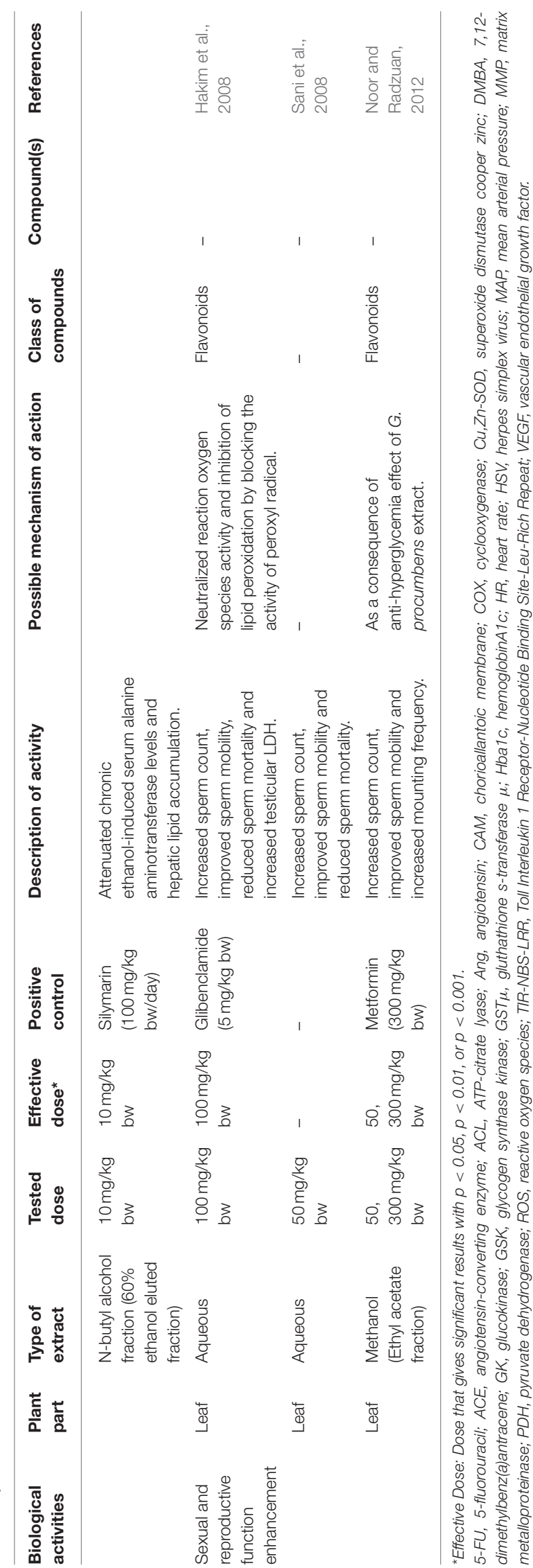

cereus, Pseudomonas aeruginosa, Vibrio parahaemolyticus, and Salmonella typhi (Rahman and Asad, 2013; Zheng et al., 2014). The antifungal activity of G. procumbens against fungi such as Candida albicans and Aspergillus niger was also observed. The findings of these studies have provided supporting evidence that substantiate the traditional use of G. procumbens in the treatment of infections by pathogens such as herpes simplex virus and malaria parasites (Kaewseejan et al., 2012; Nasir et al., 2015).

\section{Antioxidant Activity}

The antioxidant activity of G. procumbens extracts was assessed via DPPH assay to measure its free radical scavenging ability (Akowuah et al., 2009; Afandi et al., 2014). In a comparative study, the ethanol extract of $G$. procumbens exhibited the highest percentage of DPPH inhibition (52.81\%) among different types of plant extracts that were tested (Maw et al., 2011). Meanwhile, the reductive ability of $G$. procumbens extract has also been tested by using ferric reducing assay which has further proven the antioxidant capacity possessed by this plant (Kaewseejan et al., 2015).

Further examination of the antioxidant activity via a range of different assays including trolox equivalent, $\beta$-carotene-linoleic acid, and xanthine oxidase inhibitory assays have also been explored. Based on the reported data, G. procumbens was found to display substantial antioxidant activity (Rosidah et al., 2008). Since lipid peroxidation is a common result of oxidative stress, the antioxidative effect of $G$. procumbens was revealed when it inhibited lipid peroxidation with the median effective concentration of $2.75 \mathrm{mg} / \mathrm{mL}$ (Luerang et al., 2010; Kumar and Pandey, 2013). In addition, the administration of methanol extract prior to oxidative stress induction was able to reverse the elevation of plasma lipid peroxidation in tested animals (Akowuah et al., 2012). In order to differentiate the antioxidative capacity of different parts of G. procumbens, a recent study was conducted by Krishnan et al. (2015). The study revealed that the root extract showed the highest antioxidant activity when compared to the other parts of the plant. Based on the studies, $G$. procumbens appears to be a potent source of natural antioxidants probably due to its high phenolic content (Rosidah et al., 2008).

\section{Organ Protective Effect}

The protective effect of $G$. procumbens against damage of body tissues and organs has also been evaluated. G. procumbens was found to exert a gastroprotective effect as the administration of ethanolic extract significantly lessened the areas of ethanol-induced gastric ulcer in rats; with a reduction of submucosal edema and infiltration of leucocytes was observed (Mahmood et al., 2010). This finding has intrigued the researchers to further explore the protective effect of $G$. procumbens. In a study on skin damage, the antiphotoaging property of G. procumbens has been discovered as it was found to cause a significant inhibition in the expression of matrix metalloproteinases induced by ultraviolet irradiation in human dermal fibroflasts (Kim et al., 2011). The results obtained in both studies demonstrated that its protective effects might be associated with the ROS scavenging activity of G. procumbens (Mahmood et al., 2010; Kim et al., 2011). 


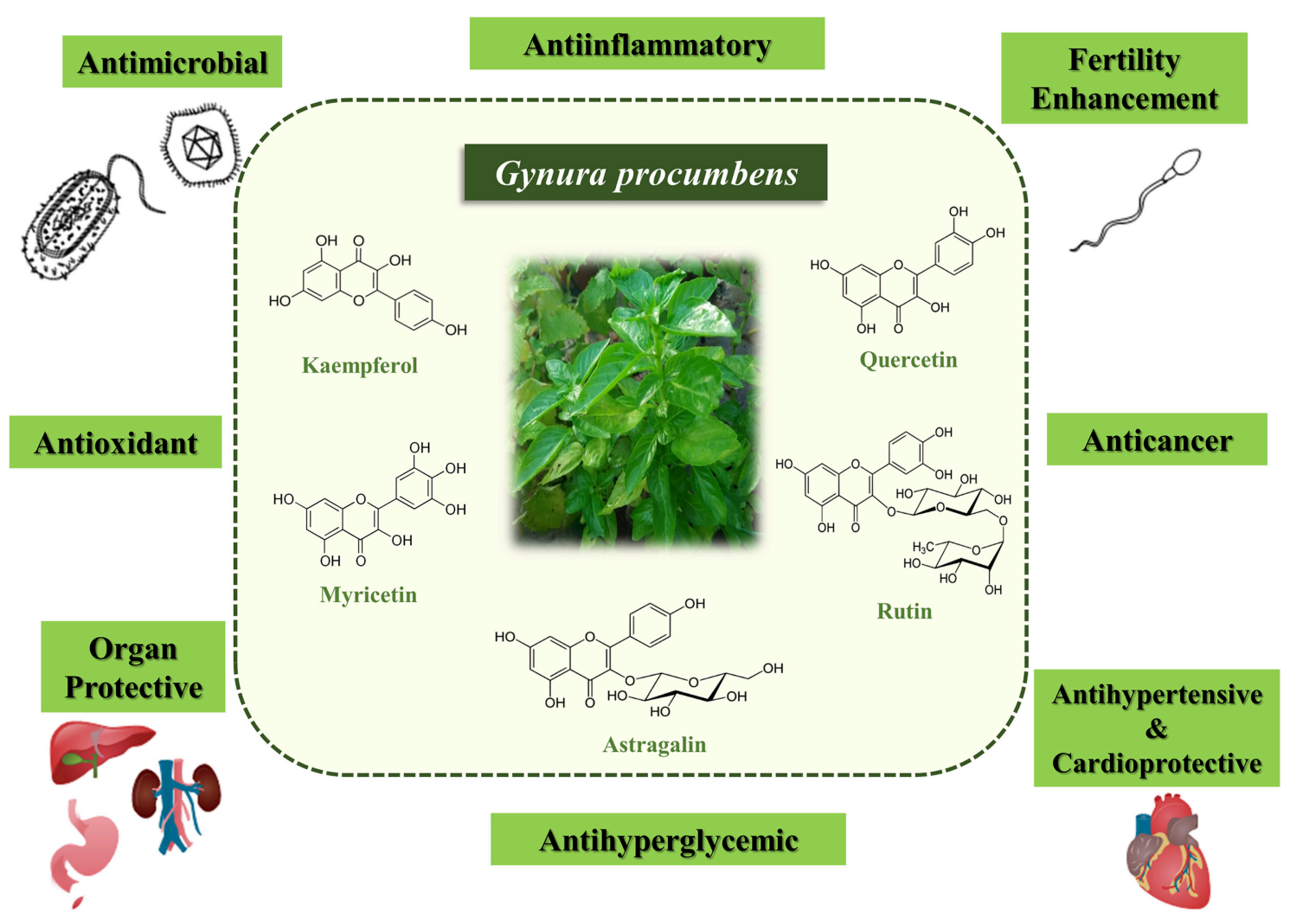

FIGURE 1 | Biological activities of Gynura procumbens and its main bioactive constituents that contributed to the biological activities.

G. procumbens is also known to be effective in preventing progressive renal diseases. The aqueous extract of plant was found to cause inhibition of mesangial cell proliferation and DNA synthesis. The suppression of regulator proteins for cell proliferation was found to be responsible for this observed effect (Lee et al., 2007). In addition, G. procumbens was found to have a hepatoprotective effect as it was shown to attenuate the ethanol-induced lipid accumulation in mice livers by modulating lipid metabolism-related genes, particularly via MAPK/SREBP1c-dependent and -independent pathways (Li et al., 2015).

Based on these findings, G. procumbens has significant potential as an organoprotective agent; mainly due to its antioxidative properties which exert a regulatory effect at the level of gene expression.

\section{Antiinflammatory Activity}

In Thai folk medicine, G. procumbens is commonly used to treat inflammation (Wiart, 2006). It was shown to prevent the increase in ear thickness of mice caused by croton oil-induced inflammation (Iskander et al., 2002). Besides, topical application of ethanol extract on the wounds of tested animals showed significant dermal healing signs, less scar width, and considerable faster healing rate when compared with control group treated with saline (Zahra et al., 2011). Furthermore, the histological analysis has also revealed there is a lesser amount of inflammatory cells at the granulation tissue of wound area and higher amount of collagen with angiogenesis.
Recently, the immunomodulatory activity of G. procumbens has been tested using mice splenic cells. The treatment of ethanolic leaf extracts of $G$. procumbens at 0.1 and $1.0 \mu \mathrm{g} / \mathrm{mL}$ caused higher proliferation of $\mathrm{CD} 4{ }^{+} \mathrm{CD} 25^{+}, \mathrm{CD} 4{ }^{+} \mathrm{CD} 62 \mathrm{~L}^{-}$, $\mathrm{CD}^{+} \mathrm{CD} 6 \mathrm{~L}^{+}, \mathrm{CD}^{+}{ }^{+} \mathrm{CD} 62 \mathrm{~L}^{-}$, and $\mathrm{CD} 8{ }^{+} \mathrm{CD}^{+} 2 \mathrm{~L}^{+} \mathrm{T}$ cells but lower proliferation of $\mathrm{B}_{2} 20^{+}$cells when compared to the higher dosage at $10 \mu \mathrm{g} / \mathrm{mL}$. However, at dosage of $10 \mu \mathrm{g} / \mathrm{mL}$, it was shown to promote high proliferation of B cells. These results have demonstrated that the concentration used in experiment is the determining factor for whether G. procumbens acts as an immunostimulant or immunosuppressant (Dwijayanti and Rifa'i, 2014, 2015).

Inflammation and the immune system are closely linked. For instance, the immune system plays a crucial role in the pathogenesis of the inflammatory disorder known as atherosclerosis which can be treated using statins-drugs with anti-inflammatory properties and immunomodulatory properties (Shovman et al., 2002). Therefore, the antiinflammatory and immunomodulatory activity of $G$. procumbens may be utilized for the treatment of inflammatory diseases or conditions that involve the immune system.

\section{Commercial Uses}

Among the existing patents related to G. procumbens, the majority of them are for preparations of traditional Chinese medicine intended for the treatment of various ailments including uterine cancer (Liao, 2015), cervical spondylosis (Shi, 
2015), and chronic skin ulcer (Yang et al., 2015). Besides, it has also been used as an ingredient in special diets for patients with medical conditions such as heart (Chen et al., 2013b) and liver disease (Chen et al., 2013a). In the food industry, it has been incorporated into products such as tea (Hu, 2014; Liao et al., 2014; Liu, 2015), kimchi (Jang, 2013), coffee powder (Park, 2015), chocolate (Jang, 2014), candy (Xie, 2007c), and chewing gum (Xie, 2010). The applications of G. procumbens in personal care and cosmetic products have also been reported which including hand-washing solution (Xie, 2009), hand sanitizer (Xie, 2007a), oral spray (Xie, 2007b), facial masks (Yuan and She, 2014), and skin care creams (Xie, 2007d). These patents have demonstrated the high commercial value of $G$. procumbens and its variety of uses in a number of industries.

\section{CONCLUSION}

In summary, G. procumbens has been demonstrated to have high therapeutic value and has enormous potential for application in the development of medical treatments as well as consumer goods. Its diverse pharmacological effects and biological

\section{REFERENCES}

Abrika, O. S. S., Yam, M. F., Asmawi, M. Z., Sadikun, A., Dieng, H., and Hussain, E. A. (2013). Effects of extracts and fractions of Gynura procumbens on rat atrial contraction. J. Acupunct. Meridian Stud. 6, 199-207. doi: 10.1016/j.jams.2013.01.020

Afandi, A., Sadikun, A., and Ismail, S. (2014). Antioxidant properties of Gynura procumbens extracts and their inhibitory effects on two major human recombinant cytochrome $\mathrm{P} 450$ s using a high throughout luminescence assay. Asian J. Pharm. Clin. Res. 7, 36-41. Available online at: http:// innovareacademics.in/journals/index.php/ajpcr/article/viewFile/1162/1476

Agustina, D., Wasito, H. S., and Supatinah, A. (2006). Anticarcinogenesis effect of Gynura procumbens (Lour) Merr on tongue carcinogenesis in 4NQO-induced rat. Dent. J. 39, 126-132. doi: 10.2174/2210315511202 040247

Akowuah, G., Ahmad, M., and Fei, Y. M. (2012). Effects of Gynura procumbens leaf extracts on plasma lipid peroxidation and total antioxidant status in CCl4-treated rats. Nat. Prod. J. 2, 247-251. doi: 10.2174/2210315511202040247

Akowuah, G., Amirin, S., Mariam, A., and Aminah, I. (2001). Blood sugar lowering activity of Gynura procumbens leaf extracts. J. Trop. Med. Plants 2, 5-10. Available online at: http://indianmedicine.eldoc.ub.rug.nl/root/A3/181a/

Akowuah, G. A., Mariam, A., and Chin, J. H. (2009). The effect of extraction temperature on total phenols and antioxidant activity of Gynura procumbens leaf. Pharmacogn. Mag. 4, 81-85. Available online at: http://www.phcog.com/ article. asp? issn $=0973-1296$; year $=2009$; volume $=5$; issue $=17$; page $=81$; epage $=85$; aulast $=$ Akowuah

Akowuah, G., Sadikun, A., and Mariam, A. (2002). Flavonoid identification and hypoglycaemic studies of the butanol fraction from Gynura procumbens. Pharm. Biol. 40, 405-410. doi: 10.1076/phbi.40.6.405.8440

Algariri, K., Atangwho, I. J., Meng, K. Y., Asmawi, M. Z., Sadikun, A., and Murugaiyah, V. (2014). Antihyperglycaemic and toxicological evaluations of extract and fractions of Gynura procumbens leaves. Trop. Life. Sci. Res. 25, 75-93.

Algariri, K., Meng, K. Y., Atangwho, I. J., Asmawi, M. Z., Sadikun, A., Murugaiyah, V., et al. (2013). Hypoglycemic and anti-hyperglycemic study of Gynura procumbens leaf extracts. Asian Pac. J. Trop. Biomed. 3, 358-366. doi: 10.1016/S2221-1691(13)60077-5

Bodeker, G., Salleh, H., and Shekar, S. C. (2009). Health and Beauty from the Rainforest: Malaysian Traditions of Ramuan. Kuala Lumpur: Editions Didier Millet Pty Ltd.

Bohari, M., Pauliena, S., Hamid, M., Shaari, K., and Lajis, N. (2006). "Glucose uptake: stimulatory activity of Gynura procumbens in 3T3-F442A adipocytes," properties (Table 1) are mainly attributed to its flavonoid content (Figure 1). However, there is still limited knowledge regarding the underlying mechanisms of action and exact chemical constituents involved. Further research elucidating the mechanisms underlying the biological activities is needed for development of standardized drugs or herbal products.

\section{AUTHOR CONTRIBUTIONS}

All authors listed, have made substantial, direct and intellectual contribution to the work, and approved it for publication.

\section{ACKNOWLEDGMENTS}

This work was supported by FRGS Grant (FRGS/1/2014/SKK01/MUSM/03/2) of Malaysia Ministry of Higher Education, MOSTI eScience Funds (02-02-10-SF0215 and 06-02-10-SF0300), and University of Malaya for High Impact Research Grant (Grant no. H-50001-A000027 and no. A000001-50001).

in Malaysian Medicinal Plant: Chemistry and Biological Activity. UNIMAS and Malaysian Natural Products Society. Available online at: http://eprints.utm.my/ 921/

Chen, X., Hu, A., and Hu, S. (2013a). Special Diet for Liver Disease Patients. CN. Patent No. 103461985. Beijing: State Intellectual Property Office of the P.R.C.

Chen, X., Hu, A., Hu, S., and Zhu, Y. (2013b). Special Diet for Heart Disease Patients. CN. Patent No. 103461986. Beijing: State Intellectual Property Office of the P.R.C.

Cheng, C.-W., Fan, W., Ko, S.-G., Song, L., and Bian, Z.-X. (2010). Evidence-based management of herb-drug interaction in cancer chemotherapy. Explore (N.Y.) 6, 324-329. doi: 10.1016/j.explore.2010.06.004

Dwijayanti, D. R., and Rifa'i, M. (2014). Immunomodulator testing on ethanol extract of Gynura procumbens leaves to Mus musculus adaptive immune system: in vitro study. J. Exp. Life Sci. 4, 10-14. Available online at: http://id. portalgaruda.org/?ref=browse\&mod=viewarticle\&article $=154403$

Dwijayanti, D. R., and Rifa'i, M. (2015). Gynura procumbens ethanolic extract promotes lymphocyte activation and regulatory $\mathrm{T}$ cell generation in vitro. J. Trop. Life Sci. 5, 14-19. Available online at: http://www.jtrolis.ub.ac.id/index. php/jtrolis/article/view/281

Gansau, J. A., Chin, L., Embi, N., and Sidek, H. M. (2012). Hypoglycemic effects of Gynura procumbens fractions on streptozotocin-induced diabetic rats involved phosphorylation of GSK3 $\beta$ (Ser-9) in liver. Sains Malays. 41, 969-975. Available online at: http://www.ukm.my/jsm/pdf_files/SM-PDF-41-8-2012/05 \%20Chong\%20Ching.pdf

Ghofur, A., Hamid, I. S., and Listyorini, D. (2015). Anti-carcinogenic activity of Gynura procumbens extract through cytochrome P450 and glutathione Stransferase. Int. J. PharmTech Res. 8, 24-29. Available online at: http://sphinxsai. com/2015/ph_vol8_no1/1/(24-29)V8N1.pdf

Gofur, A., Hamid, I. S., and Listyorini, D. (2015). Gene p53 mutations after the induction of 7,12-Dimethylbenz(a)anthracene (DMBA) and administration of anti-carcinogenesis properties of Gynura procumbens in Sprague Dawley rats. Biomed. Engin. 1, 53-57. Available online at: http://be.ub.ac.id/index.php/jibe/ article/view/17

Hakim, P., Sani, H. A., and Noor, M. M. (2008). Effects of Gynura procumbens extract and glibenclamide on sperm quality and specific activity of testicular lactate dehydrogenase in streptozotocin-induced diabetic rats. Malaysian J. Biochem. Mol. Biol. 16, 10-14. Available online at: http://ejum.fsktm.um.edu. my/article/649.pdf

Hamid, I., Dewi, R., Nazar, D., and Ratnani, H. (2013). Effectivity of Gynura procumbens extract to inhibit vascular endothelial growth factor (VEGF) expression on new blood vessels of chorioallantois membran (CAM) chicken embryonal. Veterinaria Medika 6, 27-32. Available online at: http://journal. 
unair.ac.id/effectivity-of-gynura-procumbens-extract-to-inhibit-vascularendothelial-growth-factor-(vegf)-expression-on-new-blood-vessels-ofchorioallantois-membran-(cam)-chicken-embryonal-article-6139-media-28category-5.html

Hamid, I. S. (2009). Proliferation activity of gland mammae after leaves Gynura procumbens extract which DMBA (dimethylbenz(a)antrasen) initiation on Sprague dawley rat. Media Veterinaria Medika 2, 1979-1305. Available online at: http://journal.unair.ac.id/proliferation-activity-of-gland-mammae-afterleaves-gynura-procumbens- extract-which-dmba-(dimethylbenz(a)antrasen)initiation-on-sprague-dawley-rat-article-5883-media-28-category-5.html

Hamid, I. S., Meiyanto, E., and Widyarini, S. (2009). CYP1A1 and GST $\mu$ expression of hepatocytes induced by 7,12-dimethylbenz(a)anthracene and the influence of ethanolic extract of Gynura procumbens. Indonesian J. Pharm. 20, 198-206. Available online at: http://indonesianjpharm.farmasi.ugm.ac.id/index.php/3/ article/view/529

Hamid, I. S., Wati, W. K., Mustofa, I., and Plumeriastuti, H. (2011). Activity test of Gynura procumbens leaves extract as antiangiogenic on chick embryo chorioallantoic membrane Induced by basic fibroblast growth factor (bFGF). Veterinaria Medika 4, 105-110. Available online at: http://journal.unair.ac. $\mathrm{id} /$ activity-test-of-gynura-procumbens-leaves-extract-as-antiangiogenic-onchick-embryo-chorioallantoic-membrane-induced-by-article-5866-media28-category-5.html

Hamid, M., Saufi, M., and Nik Musaadah, M. (2004). "Study on antidiabetic properties of Gynura procumbens Merr," in 18 Seminar of the Malaysian Natural Products Society (Kota Kinabalu: Universiti Malaysia Sabah).

Hassan, Z., Ahmed, M., Yosof, P., Naidu, S., Kumar, G., and Umachigi, S. (2008). Hypoglycemic effect of aqueous extract of Gynura procumbens. Pharmacologyonline 1, 30-50. Available online at: https://www.researchgate. net/publication/235329596_Hypoglycaemic_effects_of_aqueous_extract_of_ gynura_procumbens

Hassan, Z., Yam, M. F., Ahmad, M., and Yusof, A. P. M. (2010). Antidiabetic properties and mechanism of action of Gynura procumbens water extract in streptozotocin-induced diabetic rats. Molecules 15, 9008-9023. doi: 10.3390/molecules 15129008

Hew, C.-S., Khoo, B.-Y., and Gam, L.-H. (2013). The anti-cancer property of proteins extracted from Gynura procumbens (Lour.) Merr. PLoS ONE 8:e68524. doi: 10.1371/journal.pone.0068524

Hoe, S.-Z., Kamaruddin, M. Y., and Lam, S.-K. (2007). Inhibition of angiotensinconverting enzyme activity by a partially purified fraction of Gynura procumbens in spontaneously hypertensive rats. Med. Princ. Pract. 16, 203-208. doi: $10.1159 / 000100391$

Hoe, S.-Z., and Lam, S.-K. (2005). Hypotensive activity of an aqueous fraction of Gynura procumbens and possible mechanisms of action (Hypertension, Basic 1 (H), The 69th Annual Scientific Meeting of the Japanese Circulation Society). Circ. J. 69:348. Available online at: http://ci.nii.ac.jp/els/110004052875.pdf?id= ART0006313629\&type $=$ pdf\&lang $=$ en $\&$ host $=$ cinii\&order_no $=\& p p v \_t y p e=0 \&$ lang_sw $=\&$ no $=1457082856 \& \mathrm{cp}=$

Hoe, S.-Z., Lee, C.-N., Mok, S.-L., Kamaruddin, M. Y., and Lam, S.-K. (2011). Gynura procumbens Merr. decreases blood pressure in rats by vasodilatation via inhibition of calcium channels. Clinics 66, 143-150. doi: 10.1590/\$180759322011000100025

Hu, A. (2014). One Kind of Sedative Sleep-Aiding Tea. CN. Patent No. 104115963. Beijing: State Intellectual Property Office of the P.R.C.

Iskander, M., Song, Y., Coupar, I., and Jiratchariyakul, W. (2002). Antiinflammatory screening of the medicinal plant Gynura procumbens. Plant Foods Hum. Nutr. 57, 233-244. doi: 10.1023/A:1021851230890

Jang, H. S. (2013). Functional Kimchi Prepared using Gynura procumbens Leaf and use for Preventing and Treating Diabetes Mellitus. KR. Patent No. 2013019844. Daejeon: Korean Intellectual Property Office.

Jang, H. S. (2014). Method of Manufacturing Chocolate using Gynura procumbens (lour.) Merr Useful to Control Blood Sugar Level and Diabetes. KR. Patent No. 2014054534. Daejeon: Korean Intellectual Property Office.

Jarikasem, S., Charuwichitratana, S., Siritantikorn, S., Chantratita, W., Iskander, M., Frahm, A. W., et al. (2013). Antiherpetic effects of Gynura procumbens. Evid. Based Complement. Alternat. Med. 2013:394865. doi: $10.1155 / 2013 / 394865$

Jenie, R. I., Meiyanto, E., and Murwanti, R. (2006). Antiangiogenic effect of sambung nyawa leaves (Gynura procumbens (Lour.) Merr.) ethanolic extract on chick embryo chorioallantoic membrane (CAM). Indonesian J. Pharm. 17, 50-55. Available online at: http://indonesianjpharm.farmasi.ugm.ac.id/index. $\mathrm{php} / 3 /$ article/view/332

Kaewseejan, N., Puangpronpitag, D., and Nakornriab, M. (2012). Evaluation of phytochemical composition and antibacterial property of Gynura procumbens extract. Asian J. Plant Sci. 11, 77-82. doi: 10.3923/ajps.2012.77.82

Kaewseejan, N., Sutthikhum, V., and Siriamornpun, S. (2015). Potential of Gynura procumbens leaves as source of flavonoid-enriched fractions with enhanced antioxidant capacity. J. Funct. Foods 12, 120-128. doi: 10.1016/j.jff.2014.11.001

Kang, Y. H., Kim, T. W., Kim, K. K., and Choe, M. (2015). Effect of Gynura procumbens water extract on enzymes activities related with glucose metabolism in HepG2 cell. FASEB J. 29(Suppl. 730.5). Available online at: http://www.fasebj.org/content/29/1_Supplement/730.5

Kaur, N., Awadh, A. I., Ali, R. B., Sadikun, A., Sattar, M. Z. B. A., and Asmawi, M. Z. B. (2012). Cardio-vascular activity of Gynura procumbens Merr. leaf extracts. Int. J. Pharm. Sci. Res. 3, 1401-1405. Available online at: http://www.jourlib. org/paper/2737431\#.VtlNYP196M8

Kaur, P., and Bansal, M. P. (2004). Influence of selenium induced oxidative stress on spermatogenesis and lactate dehydrogenase-X in mice testis. Asian J. Androl. 6, 227-232. Available online at: http://www.asiaandro.com/archive/1008-682X/ 6/227.htm

Kim, J., Lee, C.-W., Kim, E. K., Lee, S.-J., Park, N.-H., Kim, H.-S., et al. (2011). Inhibition effect of Gynura procumbens extract on UV-B-induced matrixmetalloproteinase expression in human dermal fibroblasts. 1 J. Ethnopharm. 137, 427-433. doi: 10.1016/j.jep.2011.04.072

Kim, M.-J., Lee, H. J., Wiryowidagdo, S., and Kim, H. K. (2006). Antihypertensive effects of Gynura procumbens extract in spontaneously hypertensive rats. J. Med. Food 9, 587-590. doi: 10.1089/jmf.2006.9.587

Krishnan, V., Ahmad, S., and Mahmood, M. (2015). Antioxidant potential in different parts and callus of Gynura procumbens and different parts of Gynura bicolor. $\imath$ Biomed Res. Int. 2015, 1-7. doi: 10.1155/2015/147909

Kumar, S., and Pandey, A. K. (2013). Chemistry and biological activities of flavonoids: an overview. Sci. World J. 2013, 16. doi: 10.1155/2013/162750

Lam, S., Idris, A., Bakar, Z. A., and Ismail, R. (1998). Gynura procumbens and blood pressure in the rat: preliminary study. Asia Pac. J. Pharmacol. 13, S14.

Lee, H. J., Lee, B. C., Chung, J. H., Wiryowidagdo, S., Chun, W., Kim, S. S., et al. (2007). Inhibitory effects of an aqueous extract of Gynura procumbenson human mesangial cell proliferation. Korean J. Physiol. Pharmacol. 11, 145-148. Available online at: http://www.kjpp.net/journal/viewJournal.html? year $=2007 \&$ vol $=11$ \&page $=145$

Lee, H.-W., Hakim, P., Rabu, A., and Sani, H. A. (2012). Antidiabetic effect of Gynura procumbens leaves extracts involve modulation of hepatic carbohydrate metabolism in streptozotocin-induced diabetic rats. J. Med. Plants. Res. 6, 796-812. doi: 10.5897/jmpr11.1466

Li, X.-J., Mu, Y.-M., Li, T.-T., Yang, Y.-L., Zhang, M.-T., Li, Y.-S., et al. (2015). Gynura procumbens reverses acute and chronic ethanol-induced liver steatosis through MAPK/SREBP-1c-dependent and-independent pathways. J. Agric. Food Chem. 63, 8460-8471. doi: 10.1021/acs.jafc.5b03504

Liao, G. (2015). Traditional Chinese Medicinal Composition for Treating Uterine Cancer and its Preparation Method and Application. CN. Patent No. 105055807. Beijing: State Intellectual Property Office of the P.R.C.

Liao, W., Ling, H., She, X., and Yuan, D. (2014). Gynura procumbens Health Tea. CN. Patent No. 104171188. Beijing: State Intellectual Property Office of the P.R.C.

Liu, Y. (2015). One Kind of Passion Fruit-Honeysuckle Health Tea Granule and Preparation. CN. Patent No. 104642594. Beijing: State Intellectual Property Office of the P.R.C.

Lote, C. (2006). The renin-angiotensin system and regulation of fluid volume. Surgery 24, 154-159. doi: 10.1383/surg.2006.24.5.154

Lu, Y. L., Chia, C. Y., Liu, Y. W., and Hou, W. C. (2012). Biological activities and applications of dioscorins, the major tuber storage proteins of yam. J. Tradit. Complement. Med. 2, 41-46.

Luerang, A., Thammasarn, K., Sittiwet, C., Naowaratwattana, W., Chaichanadee, S., Puangpronpitag, D., et al. (2010). Evaluation of nutritional value and antioxidative properties of the medicinal plant Gynura procumbens extract. Asian J. Plant Sci. 9, 146-151. doi: 10.3923/ajps.2010.146.151

Mahmood, A., Mariod, A. A., Al-Bayaty, F., and Abdel-Wahab, S. I. (2010). Anti-ulcerogenic activity of Gynura procumbens leaf extract against 
experimentally-induced gastric lesions in rats. J. Med. Plants Res. 4, 685-691. doi: 10.5897/JMPR10.018

Maw, S. S., Mon, M. M., and Oo, Z. K. (2011). Study on antioxidant and antitumor activities of some herbal extracts. World Acad. Sci. Eng. Technol. 75, 450-455. Available online at: http://waset.org/publications/1716/study-on-antioxidantand-antitumor-activities-of-some-herbal-extracts

Meiyanto, E., and Jenie, R. I. (2007). Co-chemotherapy of sambung nyawa (Gynura procumbens (Lour.) Merr.) leaves ethanolic extract and doxorubicin on breast cancer cell. Indonesian J. Pharm. 18, 81-87. Available online at: http:// indonesianjpharm.farmasi.ugm.ac.id/index.php/3/article/view/447

Meiyanto, E., Susilowati, S., Tasminatun, S., and Murwanti, R. (2007). Chemopreventive effect of ethanolic extract of Gynura procumbens (Lour), Merr on the carcinogenesis of rat breast cancer development. Indonesian J. Pharm. 18, 154-161. Available online at: http://indonesianjpharm.farmasi.ugm. ac.id/index.php/3/article/view/457

Nasir, N. N. N. M., Khandaker, M. M., and Mat, N. (2015). Bioactive compound and therapeutic value of some Malaysia medicinal plants: a review. J. Agron. 14, 319-330. doi: 10.3923/ja.2015.319.330

Ng, H.-K., Poh, T.-F., Lam, S.-K., and Hoe, S.-Z. (2013). Potassium channel openers and prostacyclin play a crucial role in mediating the vasorelaxant activity of Gynura procumbens. BMC Complement. Altern. Med. 13:188. doi: 10.1186/1472-6882-13-188

Nisa, F., Hermawan, A., Murwanti, R., and Meiyanto, E. (2012). Antiproliferative effect of Gynura procumbens (lour.) Merr. Leaves etanolic extract on 7,12dimethylbenz(a)antracene induced male rat liver. Adv. Pharm. Bull. 2, 99-106. doi: 10.5681/apb.2012.014

Noor, M. M., and Radzuan, N. R. M. (2012). Anti-hyperglycemic effect of Gynura procumbens methanolic extract on fertility and libido of induced diabetic male rats. Sains Malays. 41, 1549-1556. Available online at: http://journalarticle.ukm. my/5672/1/08\%2520Mahanem.pdf

Nurulita, N. A., Meiyanto, E., Matsuda, E., and Kawaichi, M. (2012). Gynura procumbens modulates the microtubules integrity and enhances distinct mechanism on doxorubicin and 5-flurouracil-induced breast cancer cell death. Orient. Pharm. Exp. Med. 12, 205-218. doi: 10.1007/s13596-012-0063-5

Nurulita, N. A., Meiyanto, E., Sugiyanto, S., Matsuda, E., and Kawaichi, M. (2011). The ethyl acetate fraction of Gynura procumbens sensitizes widr colon cancer cell line against 5 -fluorouracil but shows antagonism with cisplatin. Int. J. Phytomed. 3, 392-405. Available online at: http://arjournals.org/index.php/ ijpm/article/view/363

Park, S. J. (2015). Method for Manufacturing Coffee Powder using Gynura procumbens. KR. Patent No. 1566475. Daejeon: Korean Intellectual Property Office.

Poh, T.-F., Ng, H.-K., Hoe, S.-Z., and Lam, S.-K. (2013). Gynura procumbens causes vasodilation by inhibiting angiotensin II and enhancing bradykinin actions. J. Cardiovasc. Pharm. 61, 378-384. doi: 10.1097/FJC.0b013e31828685b3

Pramono, S., and Nugroho, A. (2015). Effect of herbal combination of Andrographis paniculata (Burm. f) Ness and Gynura procumbens (Lour.) Merr ethanolic extracts in alloxan-induced hyperglycemic rats. Int. Food Res. J. 22, 1332-1337. Available online at: http://www.ifrj.upm.edu.my/22\%20(04) $\% 202015 /(3) . p d f$

Quattrocchi, U. (2012). CRC World Dictionary of Medicinal and Poisonous Plants: Common Names, Scientific Names, Eponyms, Synonyms, and Etymology (5 Volume Set). Boca Raton, FL: CRC Press.

Rahman, A., and Asad, M. (2013). Chemical and biological investigations of the leaves of Gynura procumbens. Int. J. Biosci. 3, 36-43. doi: 10.12692/ijb/3.4.36-43

Ramalho-Santos, J., Amaral, S., and Oliveira, P. J. (2008). Diabetes and the impairment of reproductive function: possible role of mitochondria and reactive oxygen species. Curr. Diabetes Rev. 4, 46-54. doi: 10.2174/157339908783502398

Rosidah, Yam, M., Sadikun, A., and Asmawi, M. (2008). Antioxidant potential of Gynura procumbens. Pharm. Biol. 46, 616-625. doi: $10.1080 / 13880200802179642$

Sani, H. A., Darus, N. A., Noor, M. M., and Ismail, I. I. (2008). Gynura procumbens leaves aqueous extract decreased blood glucose level and increased sperm quality in diabetic-induced rats. Sains Malays. 37, 435-441. Available online at: http://www.ukm.my/jsm/english_journals/vol37num4_ 2008/vol37num4_08page435-441.html

Shi, Z. (2015). Chinese Medicinal Composition for Treatment of Cervical Spondylosis and Preparation Method Thereof. CN. Patent No. 104815225. Beijing: State Intellectual Property Office of the P.R.C.
Shovman, O., Levy, Y., Gilburd, B., and Shoenfeld, Y. (2002). Antiinflammatory and immunomodulatory properties of statins. Immunol. Res. 25, 271-285. doi 10.1385/IR:25:3:271

Shwter, A. N., Abdullah, N. A., Alshawsh, M. A., Alsalahi, A., Hajrezaei, M., Almaqrami, A. A., et al. (2014). Chemoprevention of colonic aberrant crypt foci by Gynura procumbens in rats. 2 . Ethnopharm. 151, 1194-1201. doi: 10.1016/j.jep.2013.12.044

Sunarwidhi, A. L., Sudarsono, S., and Nugroho, A. E. (2014). Hypoglycemic effect of combination of Azadirachta indica A. Juss. and Gynura procumbens (Lour.) Merr. ethanolic extracts standardized by rutin and quercetin in alloxaninduced hyperglycemic rats. Adv. Pharm. Bull. 4, 613. doi: 10.5681/apb. 2014.090

Tan, L. T. H., Lee, L. H., Yin, W. F., Chan, C. K., Abdul Kadir, H., Chan, K. G., et al. (2015). Traditional uses, phytochemistry, and bioactivities of Cananga odorata (Ylang-Ylang). Evid. Based Complement. Alternat. Med. 2015:896314. doi: 10.1155/2015/896314

Vejanan, V., Latip, J., Chin, L. P., Embi, N., and Sidek, H. M. (2012). In vitro and in vivo anti-plasmodial activities of Gynura procumbens. Sains Malays. 41, 1535-1542. Available online at: http://www.ukm.my/jsm/pdf_files/SM-PDF41-12-2012/06\%20Visalini.pdf

Wang, H., Zhou, J. W., Fu, D. H., Zhou, Y., Cheng, W. Z., and Liu, Z. L. (2013). Gynura procumbens ethanolic extract suppresses osteosarcoma cell proliferation and metastasis in vitro. Oncol. Lett. 6, 113-117. doi: $10.3892 / \mathrm{ol} .2013 .1315$

Wiart, C. (2006). Medicinal Plants of Asia and the Pacific. Boca Raton, FL: CRC Press.

Xie, P. (2007a). Hand Sanitizer Containing Gynura procumbens Extract. CN. Patent No. 101036629. Beijing: State Intellectual Property Office of the P.R.C.

Xie, P. (2007b). Oral Sprays Containing Gynura Extracts and Metronidazole and Sodium Chlorophyllin. CN. Patent No. 101032539. Beijing: State Intellectual Property Office of the P.R.C.

Xie, P. (2007c). Production of Candy for Nourishing Throat from Gynura procumbens. CN. Patent No. 101061823. Beijing: State Intellectual Property Office of the P.R.C.

Xie, P. (2007d). Skin Care Creams Containing Gynura Extracts. CN. Patent No. 101032458. Beijing: State Intellectual Property Office of the P.R.C.

Xie, P. (2009). Gynura procumbens Hand-Washing Solution and the Method for Preparing the Same. CN. Patent No. 100490779 C. Beijing: State Intellectual Property Office of the P.R.C.

Xie, P. (2010). Gynura procumbens Chewing Gums. CN. Patent No. 101036679 B. Beijing: State Intellectual Property Office of the P.R.C.

Yang, X., Wang, J., and Xu, Y. (2015). A Traditional Chinese Medicine Preparation for Treating Damp Heat Toxin Accumulation Type Chronic Skin Ulcer and its Production Method. CN. Patent No. 104666446. Beijing: State Intellectual Property Office of the P.R.C.

Yuan, D., and She, X. (2014). A Kind of Gynura procumbens (lour.) merr. Instant Polynary Maintenance Natural Compound Facial Mask and Preparation Method Thereof. CN. Patent No. 103961301. Beijing: State Intellectual Property Office of the P.R.C.

Zahra, A. A., Kadir, F. A., Mahmood, A. A., Al hadi, A. A., Suzy, S. M., Sabri, S. Z., et al. (2011). Acute toxicity study and wound healing potential of Gynura procumbens leaf extract in rats. J. Med. Plant Res. 5, 2551-2558. Available online at: http://repository.um.edu.my/13707/1/Zahra\%20Wound.pdf

Zhang, X., and Tan, B. (2000). Effects of an ethanolic extract of Gynura procumbens on serum glucose, cholesterol and triglyceride levels in normal and streptozotocin-induced diabetic rats. Singapore Med. J. 41, 9-13. doi: 10.5897/ajb11.2980

Zheng, G.-D., Shuai, L.-Q.-W., Li, D.-M., and Zhu, Y.-T. (2014). Extraction and antibacterial effects of Gynura procumbens leaves. Shipin Keji 39, 218-221.

Conflict of Interest Statement: The authors declare that the research was conducted in the absence of any commercial or financial relationships that could be construed as a potential conflict of interest.

Copyright (c) 2016 Tan, Chan, Pusparajah, Lee and Goh. This is an open-access article distributed under the terms of the Creative Commons Attribution License (CC BY). The use, distribution or reproduction in other forums is permitted, provided the original author(s) or licensor are credited and that the original publication in this journal is cited, in accordance with accepted academic practice. No use, distribution or reproduction is permitted which does not comply with these terms. 